\title{
Paepalanthus subgen. Xeractis (Eriocaulaceae) na porção central da Cadeia do Espinhaço em Minas Gerais, Brasil
}

Paepalanthus subgen. Xeractis (Eriocaulaceae) in the central Espinhaço Range in Minas Gerais, Brazil

\author{
Caroline Oliveira Andrino ${ }^{1,3}$ \& Fabiane Nepomuceno Costa ${ }^{2}$
}

\begin{abstract}
Resumo
Dentre as famílias botânicas que ocorrem nos campos rupestres, Eriocaulaceae destaca-se como uma das mais representativas, tanto pela grande riqueza, como pelo elevado número de endemismos. A família é composta atualmente por 10 gêneros. Paepalanthus Mart. possui ca. 400 espécies agrupadas em vários táxons infragenéricos, entre eles Paepalanthus subgen. Xeractis Koern., grupo endêmico da Cadeia do Espinhaço em Minas Gerais. Foi efetuado o levantamento das espécies de Paepalanthus subgen. Xeractis que ocorrem na porção central da Cadeia do Espinhaço em Minas Gerais, principal centro de diversidade do gênero. Foram registradas 10 espécies e duas variedades: $P$. argenteus (Bong.) Koern. var. argenteus, $P$. calvulus (Ruhland) Hensold, $P$. chrysolepis Silveira, $P$. comans Silveira, P. dianthoides Mart., P. homomallus (Bong.) Mart., P. latifolius Koern., P. mollis var. itambeensis Hensold, P. nigrescens Silveira, P. plumosus (Bong.) Koern., P. revolutus Hensold e P. superbus (Silveira) Hensold. São apresentadas chaves de identificação para os subgêneros de Paepalanthus e espécies de $P$. subgen. Xeractis, além de descrições e comentários sobre morfologia, distribuição geográfica, hábitat e conservação das espécies.

Palavras-chave: campos rupestres, flora, taxonomia.
\end{abstract}

\begin{abstract}
Among the plant families that occur in the campos rupestres, Eriocaulaceae stands out as one of the most representative, in the number of species, and also in the number of endemic species. Currently the family is composed of 10 genera. Paepalanthus Mart. comprises $c a$. 400 species grouped in many infrageneric taxa, among them, Paepalanthus subgen. Xeractis Koern., subgenus endemic of the Espinhaço Range in Minas Gerais State. Our study presents information about species of Paepalanthus subgen. Xeractis that occur in the central Espinhaço Range in Minas Gerais, the main diversity centre of Paepalanthus. Ten species and two varieties were found: Paepalanthus argenteus (Bong.) Koern. var. argenteus, P. calvulus (Ruhland) Hensold, P. chrysolepis Silveira, $P$. comans Silveira, P. dianthoides Mart., P. homomallus (Bong.) Mart., P. latifolius Koern., P. mollis var. itambeensis Hensold, $P$. nigrescens Silveira, $P$. plumosus (Bong.) Koern., P. revolutus Hensold, and $P$. superbus (Silveira) Hensold. We present identification keys for the subgenera of Paepalanthus and for species of $P$. subgen. Xeractis, and also descriptions and comments about morphology, geographical distribution and conservation of the species. Key words: "campos rupestres", flora, taxonomy.
\end{abstract}

\section{Introdução}

Eriocaulaceae é composta por cerca de 1400 espécies distribuídas em 10 gêneros. Representantes desta família podem ser facilmente reconhecidos pela presença de inflorescências capituliformes (Giulietti et al. 2012). O gênero Paepalanthus Mart. é o segundo maior da família, com aproximadamente 400 espécies, ocorrendo principalmente nas Américas Central e do Sul, e cinco na África (Giulietti \& Hensold 1990).
No Brasil, Paepalanthus está representado por 357 espécies, sendo o maior gênero de Angiospermas do território brasileiro (Forzza et al. 2010), amplamente distribuído desde a Região Norte até a Região Sul, mas com centro de diversidade nos campos rupestres da Cadeia do Espinhaço. Estimativas indicam que ocorrem cerca de 220 espécies de Paepalanthus ao longo desta formação geológica, sendo $85 \%$ delas endêmicas e algumas com distribuição bastante restrita (Costa et al. 2008).

\footnotetext{
${ }^{1}$ Universidade de São Paulo, Depto. Botânica, Inst. Biociências, Lab. Sistemática Vegetal, R. do Matão 277, Cidade Universitária, 05508-900, São Paulo, SP, Brasil.

${ }^{2}$ Universidade Federal dos Vales do Jequitinhonha e Mucuri, Depto. Ciências Biológicas, Campus JK, BR-367, 39100-000, Diamantina, MG, Brasil.

${ }^{3}$ Autor para correspondencia: carolineandrino@yahoo.com.br
} 
A última revisão taxonômica da família (Ruhland 1903) propôs a divisão de Paepalanthus em seis subgêneros. Alguns táxons infragenéricos foram revisados recentemente (Tissot-Squalli 1997; Sano 1999; Costa 2005; Trovó 2010), dentre eles Paepalanthus subgen. Xeractis Koern. (Hensold 1988). Este subgênero foi considerado como um grupo natural desde Ruhland (1903) e os estudos de Echternacht et al. (2011a) confirmam o monofiletismo do grupo. Atualmente Paepalanthus subgen. Xeractis compreende 28 espécies endêmicas da Cadeia do Espinhaço em Minas Gerais, a maioria com distribuição muito restrita (Hensold 1988, 1996). É facilmente reconhecido pelas brácteas involucrais ultrapassando a altura das flores (exceto em duas espécies) e pela pilosidade interna da corola da flor estaminada. Além da revisão do subgênero (Hensold 1988) há também um levantamento florístico publicado por Hensold (1998) para a Serra do Cipó.

Sabe-se que a porção central da Cadeia do Espinhaço em Minas Gerais representa um centro de diversidade local de muitos grupos de Eriocaulaceae (Costa et al. 2008). Esta parte do Espinhaço engloba regiões consideradas como prioritárias para a conservação da flora de Minas Gerais, como o Planalto de Diamantina e Serra do Cabral (Drummond et al. 2005). Em relação às Eriocaulaceae, nos últimos anos foram descritas e redescobertas novas espécies para esta porção do Espinhaço, inclusive de grupos revisados recentemente (Costa 2006; Trovó \& Costa 2009; Trovó \& Sano 2010; Echternacht et al. 2011b; Trovó et al. 2012), o que reforça a necessidade de estudos florísticos nesta região, mesmo em grupos com revisões recentes.

Este estudo teve como objetivo efetuar o levantamento das espécies de Paepalanthus subgen. Xeractis na porção central da Cadeia do Espinhaço, em Minas Gerais, apresentando chaves de identificação, ilustrações, dados sobre morfologia, distribuição geográfica e conservação das espécies.

\section{Material e Métodos}

A área de estudo está situada entre as serras do município de Congonhas do Norte ao sul, e ao norte pelo município de Olhos d'Água e Bocaiúva, incluindo também a Serra do Cabral, a oeste, nas coordenadas de $44^{\circ} 30^{\prime}-43^{\circ} 15^{\prime} \mathrm{W}$ e $18^{\circ} 58^{\prime}-17^{\circ} 30^{\prime} \mathrm{S}$ (Fig. 1). Apresenta altitudes variando entre $900 \mathrm{e}$ $2050 \mathrm{~m}$, clima do tipo mesotérmico (Cwb sensu Koeppen 1931), precipitação média anual de 1050 $\mathrm{mm}$ e temperatura média de $19^{\circ} \mathrm{C}$. A porção central do Espinhaço, no estado de Minas Gerais, está inserida no domínio do Cerrado, tendo como cobertura vegetal dominante o campo rupestre. A área engloba as seguintes Unidades de Conservação (UCs): Parque Nacional das Sempre Vivas, Parque Estadual (PE) da Serra do Cabral, PE do Pico do Itambé, PE do Rio Preto e PE do Biribiri (Drummond et al. 2005).

Foram realizadas expedições mensais para coleta de material entre agosto de 2009 e maio de 2011. Todo o material coletado foi georreferenciado, prensado, seco em estufa e, posteriormente montado em exsicatas, que foram depositadas no herbário da Universidade Federal dos Vales do Jequitinhonha e Mucuri (DIAM). Também foram examinadas as coleções dos seguintes herbários: BHCB, MBM, OUPR, R, RB, SPF e UB (acrônimos de acordo com Thiers 2012).

Os espécimes foram examinados com auxílio de microscópio estereoscópico e identificados utilizando-se principalmente a revisão taxonômica do subgênero (Hensold 1988). Para a contagem das flores, foram retirados aleatoriamente dez capítulos de diferentes exsicatas de cada espécie, sendo calculada a proporção de flores pistiladas e estaminadas por espécie, além dos valores mínimos e máximos do total de flores. Para as espécies com poucos materiais, as flores não foram contadas. As descrições morfológicas seguiram a terminologia proposta por Radford (1974) e foi baseada apenas nos materiais examinados, listados por ordem alfabética de município e cronológica, respectivamente. Alguns materiais do herbário SPF listados fazem parte da Coleção Flora da Serra do Cipó (CFSC) ou Coleção Flora dos Campos Rupestres (CFCR), não havendo um número específico do coletor e sim da coleção. Nesses casos, logo após o nome do coletor (ou coletores), foi citada a sigla da coleção e seu respectivo número.

É apresentado um mapa de distribuição geográfica das espécies na área de estudo (Fig. 1), no entanto foram marcados apenas os pontos cujos materiais examinados apresentavam coordenadas geográficas.

\section{Resultados e Discussão}

Foi registrada a ocorrência de 10 espécies e duas variedades para a porção central da Cadeia do Espinhaço em Minas Gerais, sendo que destas, P. chrysolepis Silveira, P. comans Silveira e $P$. mollis var. itambeensis Hensold são exclusivas desta área. Paepalanthus latifolius (Bong.) Koern. pode ser considerada como endêmica do Planalto de Diamantina, pois apesar do tipo ser proveniente da Serra do Cipó, não foi registrado qualquer ocorrência posterior a este. 


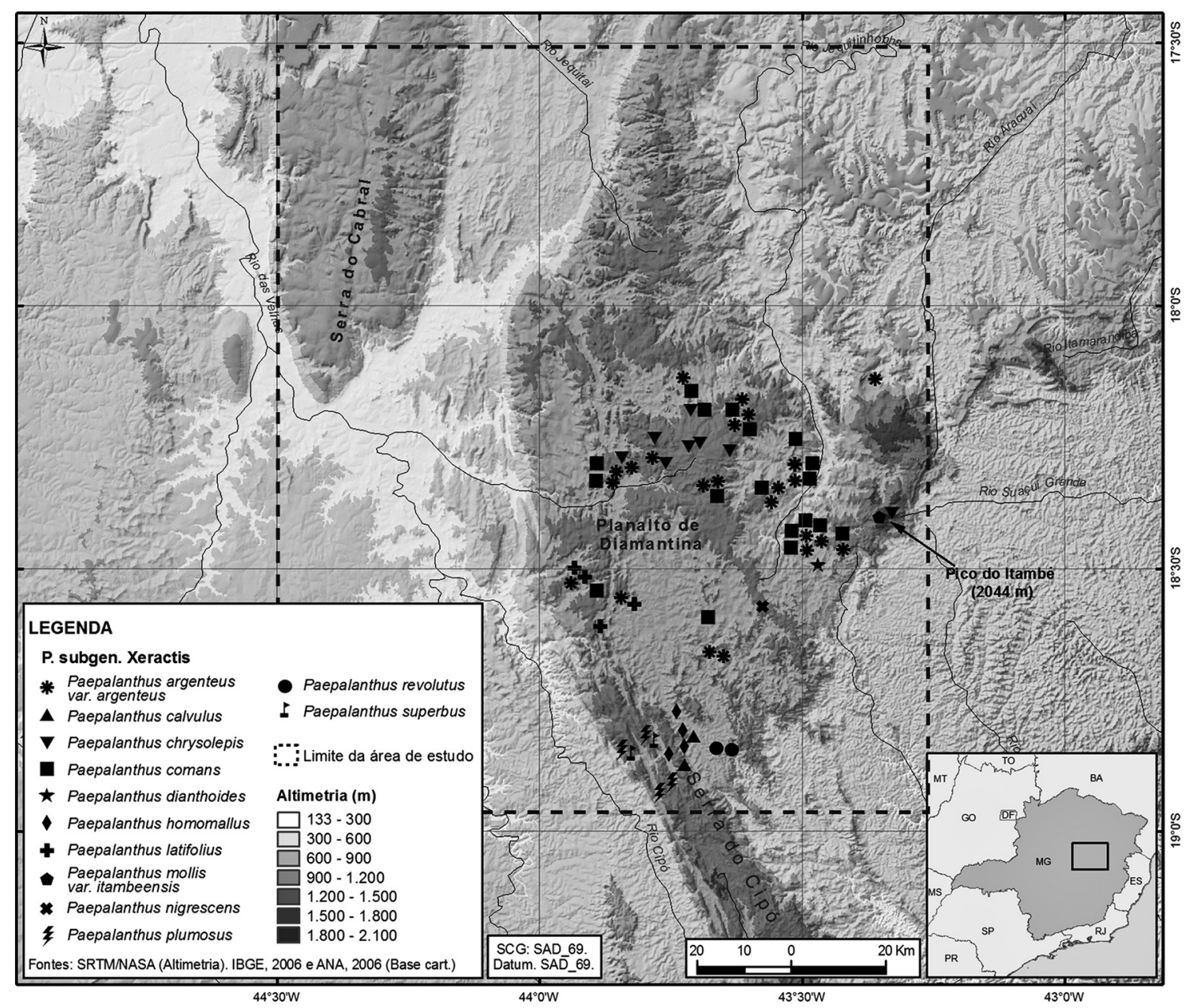

Figura 1 - Mapa de distribuição de Paepalanthus subgen. Xeractis na porção central da Cadeia do Espinhaço em Minas Gerais.

Figure 1 - Distribution map of Paepalanthus subgen. Xeractis in the central portion of the Espinhaço Range in Minas Gerais.

Outras cinco espécies são restritas à porção norte da Serra do Cipó e de serras de Congonhas do Norte, limite sul da área de estudo. São elas: P. calvulus (Ruhland) Hensold, P. homomallus (Bong.) Mart. ex Koern., P. plumosus (Bong.) Koern., P. revolutus Hensold e P. superbus Ruhland. Estes táxons, apesar de ocorrerem também na Serra do Cipó, não foram tratados por Hensold (1998), por não ocorrerem na área que havia sido delimitada para aquele estudo. Paepalanthus argenteus var. elatus (Bong.) Hensold é outro táxon referido para a Serra do Cipó e para a porção sul da área de estudo, tendo sido recoletado recentemente, após 183 anos sem registros de coleta (Echternacht et al. 2010).
Entretanto, este espécime não foi localizado nos herbários citados pelos autores e novos exemplares não foram encontrados durante as coletas realizadas.

As demais espécies registradas para a porção central do Espinhaço em Minas Gerais são comuns à área de estudo e a Serra do Cipó, sendo P. argenteus (Bong.) Koern. var. argenteus bastante abundante ao longo de todo o Espinhaço mineiro; P. nigrescens (Silveira) Hensold é muito comum na Serra do Cipó, e com apenas uma população disjunta no Planalto de Diamantina; e $P$. dianthoides Mart. ex Koern., comum na porção sul da Cadeia do Espinhaço, mas rara na Serra do Cipó (Hensold 1998) e no Planalto de Diamantina. 


\section{Chave de identificação para os subgêneros de Paepalanthus que ocorrem na porção central da Cadeia do Espinhaço em Minas Gerais}

1. Planta sem espatas e escapos P. subgen. Thelxinöe

1'. Planta com espatas e escapos.

2. Escapos unidos entre si P. subgen. Platycaulon

2'. Escapos livres entre si.

3. Corola da flor estaminada pilosa no interior do tubo P. subgen. Xeractis

3'. Corola da flor estaminada glabra $P$. subgen. Paepalocephalus

Paepalanthus subgen. Xeractis Koern.

Ervas perenes, caules aéreos reduzidos a alongados. Folhas rosuladas, espiraladas ou alternas dísticas, lanceoladas a lineares, com tricomas filamentosos, unisseriados. Brácteas involucrais castanhas, creme ou douradas. Flores trímeras. Brácteas florais presentes, membranáceas. Flores estaminadas pediceladas; sépalas douradas ou creme, oblongas ou elípticas, fundidas brevemente na base ou, raramente, até $2 / 3$ do seu comprimento; corola gamopétala, creme ou castanho-escura, hialina, com lobos largos, obtusos a truncados, pilosas internamente; estames livres das pétalas, anteras creme a castanho-escuras. Flores pistiladas pediceladas, com sépalas semelhantes na forma e pilosidade às flores estaminadas, tornando-se rígidas e douradas a castanhas na maturidade dos frutos; pétalas pigmentadas como os segmentos da corola das flores estaminadas, elípticas ou espatuladas, obtusas ou amplamente arredondadas e frequentemente côncavas, estaminódios escamiformes opostos às pétalas; ramos estigmáticos bífidos. Fruto do tipo cápsula com sementes avermelhadas ou castanho-escuras.

\section{Chave de identificação das espécies de Paepalanthus subgen. Xeractis da porção central da Cadeia do Espinhaço em Minas Gerais, Brasil}

1. Brácteas involucrais castanhas a marrom escuras.

2. Brácteas involucrais da mesma altura das flores no capítulo ou menores.

3. Folhas lineares, pubescentes a lanuginosas em ambas as faces, ápice arredondado

6. P. homomallus

3'. Folhas lanceoladas, glabrescentes em ambas as faces, ápice agudo a obtuso

9. P. nigrescens

2'. Brácteas involucrais ultrapassando a altura das flores no capítulo.

4. Caule visivelmente alongado, acima de $6 \mathrm{~cm}$ compr.

5. Brácteas involucrais recurvadas, mesmo no botão

11. P. revolutus

5'. Brácteas involucrais não recurvadas.

6. Plantas escandentes, folhas espiraladas ao longo do caule

5. P. dianthoides

6'. Plantas eretas, folhas alternas dísticas

12. P. superbus

4'. Caule curto, não ultrapassando $5 \mathrm{~cm}$ compr.

7. Indivíduos cespitosos; capítulos 6-12 mm diâm.

8. P. mollis var. itambeensis

7’. Indivíduos não cespitosos; capítulos 13-18 mm diâm.

8. Brácteas involucrais externas mais claras que as internas; bráctea floral com pigmentação enegrecida no ápice

4. P. comans

8'. Brácteas involucrais de cor uniforme; bráctea floral sem pigmentação

10. P. plumosus

1'. Brácteas involucrais creme a douradas.

9. Anteras castanho-escuras

2. P. calvulus

9'. Anteras creme.

10. Folhas seríceas

1. P. argenteus var. argenteus

10'. Folhas pubescentes a glabras 11

11. Folhas 3-9 mm larg.; brácteas florais com 2-3 mm compr. 3. P. chrysolepis

11'. Folhas 9-27 mm larg.; brácteas florais com 7-8 mm compr. 7. P. latifolius 
1. Paepalanthus argenteus (Bong.) Koern. var. argenteus, Fl. bras. 3(1): 343. 1863.

Erva $15-42 \mathrm{~cm}$ alt. Caule restrito à roseta. Folhas rosuladas, $(2,5-) 6-35,5 \times(0,3-) 0,6-2 \mathrm{~cm}$, lanceoladas, agudas, densamente seríceas na face abaxial, seríceas a pubescentes na face adaxial. Espatas 1,4-6,5 cm compr., ápice arredondado a agudo, margem irregular, seríceas a pubescentes. Escapos 4,5-37 cm compr., pilosos a pubescentes. Brácteas involucrais creme a douradas, 5-11 × 2-6 $\mathrm{mm}$, triangulares, ápice agudo, não recurvadas, ultrapassando a altura das flores em 1-6 mm, pubescentes externamente. Capítulos ocre, 5-18 mm diâm. Flores de 112 a 139 por capítulo, 2 vezes mais estaminadas que pistiladas. Brácteas florais hialinas, ca. $4 \times 0,5 \mathrm{~mm}$, lanceoladas, ápice agudo a acuminado, ciliadas. Flores estaminadas ca. $4 \mathrm{~mm}$ compr.; pedicelo ca. 1,2 mm compr.; sépalas hialinas, ca. $3 \times 0,5 \mathrm{~mm}$, elípticas a oblanceoladas, ápice obtuso, com tricomas em tufos na porção apical; corola hialina, ca. 3,5 mm compr.; estames ca. 3 $\mathrm{mm}$ compr., anteras creme. Flores pistiladas $4-6 \mathrm{~mm}$ compr., pedicelo ca. $1 \mathrm{~mm}$ compr., sépalas hialinas, 3,5-5 × 0,8-1 mm, obovadas, ápice obtuso, com tricomas na porção apical; pétalas hialinas, 3-4,5 × $1,5 \mathrm{~mm}$, obovadas, ápice obtuso, com tricomas nas margens e no ápice.

Material selecionado: Datas, $\mathrm{km} 605$ da rodovia Diamantina-Datas, 18.VI.2000, fl., F.N. Costa et al. 197 (SPF). Diamantina, campus JK da Universidade Federal dos Vales do Jequitinhonha e Mucuri, 25.VIII.2009, fl., C.O. Andrino et al. 13 (DIAM); estrada para Milho Verde, 25.IX.2009, fl., C.O. Andrino et al. 16 (DIAM); Gouveia, Fazenda Contagem, $13 \mathrm{~km}$ da rodovia CurveloDiamantina, 29.VIII.1981, fl., A.M. Giulietti et al. CFCR 1761 (SPF). Presidente Juscelino, ca. de $1 \mathrm{~km}$ na estrada para Datas, 23.II.1982, fl., N. Hensold 517 (SPF). São Gonçalo do Rio Preto, Parque Estadual do Rio Preto, 8.II.2010, fl., C.O. Andrino et al. 28 (DIAM). Serro, estrada Diamantina-Milho Verde, 29.VII.1999, fl., P.T. Sano et al. 1012 (SPF).

Paepalanthus argenteus var. argenteus pode ser facilmente distinguida pelas brácteas involucrais douradas e pela pilosidade serícea das folhas.

É o táxon mais comum de $P$. subgen. Xeractis no Planalto de Diamantina (Fig. 1), ocorrendo entre 1000 a $1600 \mathrm{~m}$ de altitude, geralmente em solos profundos e bem drenados. Devido à sua ampla distribuição em toda a área de ocorrência do subgênero, com populações numerosas, pode se afirmar que não está ameaçada de extinção. É bastante representada nos herbários, tendo sido registradas 70 coleções desta variedade apenas para a área de estudo, inclusive em UCs, como o PE do Rio Preto e PE do Biribiri.
Foi coletada com flores durante todo o ano, sem registros de picos de floração.

2. Paepalanthus calvulus (Ruhland) Hensold, Syst. Bot. Monogr. 23: 119. $1988 . \quad$ Fig. 2a-b

Erva ca. $40 \mathrm{~cm}$ alt. Caule restrito à roseta. Folhas rosuladas, $12-30 \times 1-2 \mathrm{~cm}$, lanceoladas, agudas, glabras a pubescentes em ambas as faces. Espatas 8-9 cm compr., ápice acuminado a agudo, margem irregular, glabras a pubescentes. Escapos 21-35 cm de compr., pubescentes. Brácteas involucrais douradas, $10-14 \times 3-5 \mathrm{~mm}$, triangulares, ápice agudo, recurvadas na maturidade, ultrapassando a altura das flores por $6-10 \mathrm{~mm}$, glabras. Capítulos alvos, 11-20 mm diâm. Flores de 252 a 364 por capítulo, 5 vezes mais estaminadas que pistiladas. Brácteas florais hialinas, ca. $4 \times 0,5$ $\mathrm{mm}$, lanceoladas, aguda a acuminada, ciliada. Flores estaminadas 4-6 mm compr., pedicelo ca. $1,5 \mathrm{~mm}$ compr.; sépalas hialinas, ca. $6 \times 0,9 \mathrm{~mm}$, elípticas a oblanceoladas, ápice obtuso a acuminado, com tricomas em tufos na porção apical; corola hialina, 2,5-4 × 1,5 mm; estames 2-4 mm compr.; anteras castanho-escuras. Flores pistiladas $4-5 \mathrm{~mm}$ compr., pedicelo ca. 0,2 $\mathrm{mm}$ compr.; sépalas hialinas, $4-5 \times$ 0,7-1 mm, lanceoladas, ápice agudo a acuminado, com tricomas na porção apical; pétalas hialinas 3-4× $1,5 \mathrm{~mm}$, lanceoladas, ápice agudo a acuminado, com tricomas na face adaxial, nas margens e no ápice.

Material examinado: Congonhas do Norte, Serra da Carapina (Serra Talhada na folha IBGE), setor norte da Serra do Cipó, 2.III.1998, fl., J.R. Pirani et al. 4109 (SPF); acesso à direita da estrada Diamantina-Congonhas do Norte, ca. de $4 \mathrm{~km}$ antes da cidade, alto da Serra, 18.VI.2010, f1., C.O. Andrino et al. 72 (DIAM).

Paepalanthus calvulus pode ser facilmente distinguida das demais espécies que possuem brácteas involucrais creme a douradas por possuir anteras castanho-escuras.

Esta espécie é endêmica do município de Congonhas do Norte, e era conhecida de uma única população (Hensold 1988), tendo sido recoletada no presente estudo (Fig. 1), encontrada em fendas de rochas, em locais parcialmente sombreados. O material tipo é referido para Diamantina, no entanto, não foi encontrada nenhuma população nesta área, o que confirma o discutido por Hensold (1988) sobre uma possível troca de etiquetas de material. Provavelmente trata-se de uma espécie rara e com uma distribuição muito restrita, embora não seja possível afirmar se está ameaçada, devido à escassez de informações populacionais.

Há registros de coleta de P. calvulus com flor entre março e junho. 


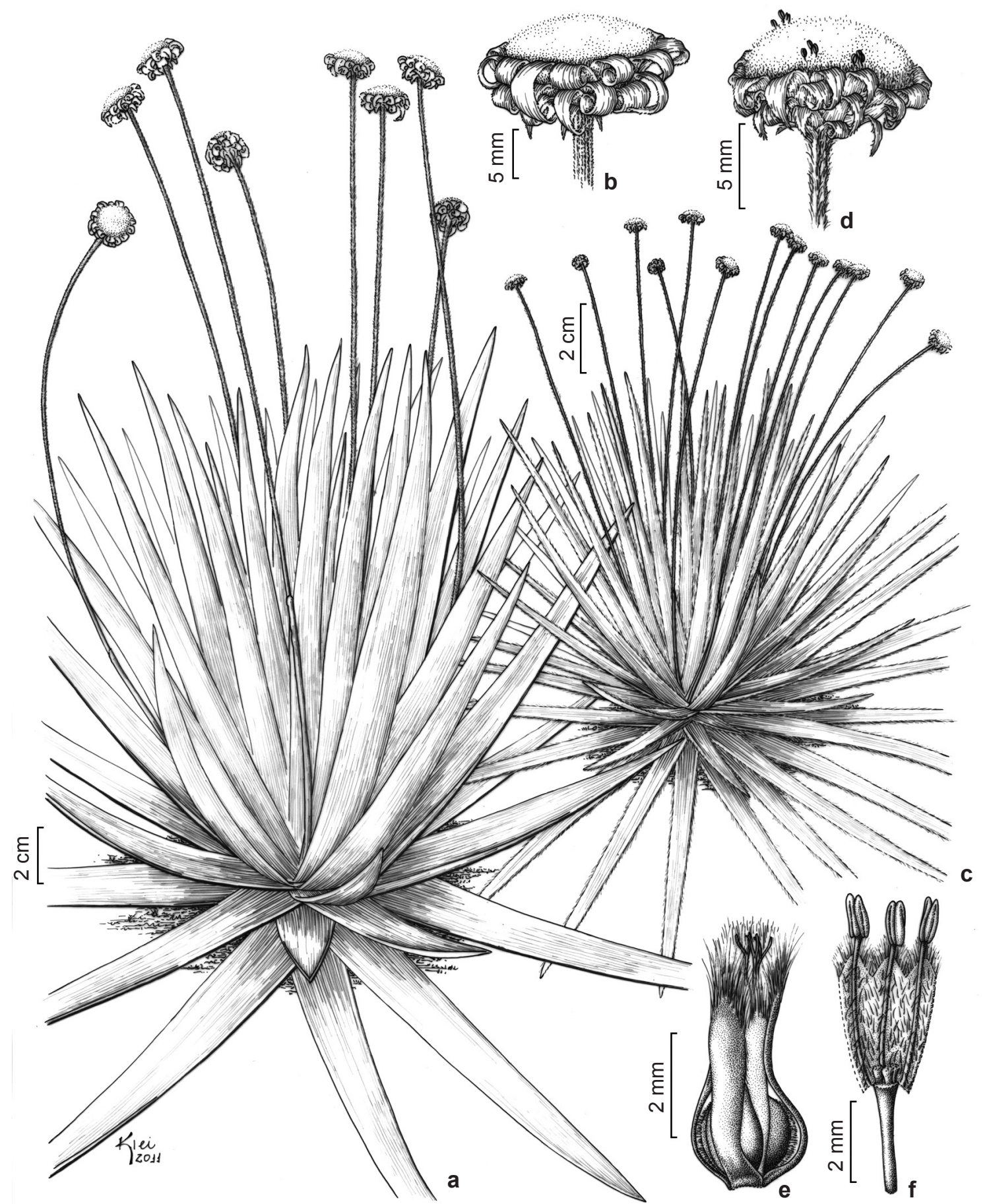

Figura 2 - a-b. Paepalanthus calvulus - a. hábito, b. capítulo (C.O.Andrino 72 (DIAM)). c-d. P. chrysolepis - c. hábito; d. capítulo (C.O.Andrino 94 (DIAM)). e-f. P. comans - e. flor pistilida; f. flor estaminada com sépalas removidas e tubo da corola aberto (C.O.Andrino 109 (DIAM)).

Figure 2 - a-b. Paepalanthus calvulus - a. habit; b. capitulum (C.O.Andrino 72 (DIAM)). c-d. P. chrysolepis - c. habit, d. capitulum (C.O.Andrino 94 (DIAM)). e-f. P. comans - e. pistillate flower; f. staminate flower with sepals removed and opened corolla (C.O.Andrino 109 (DIAM)). 
3. Paepalanthus chrysolepis Silveira, Floral. Mont. 256. 1928

Fig. 2c-d

Erva $20-35 \mathrm{~cm}$ alt. Caule restrito à roseta. Folhas rosuladas, $6-16 \times 0,3-0,9 \mathrm{~cm}$, lanceoladas, agudas, pubescentes a totalmente glabras em ambas as faces. Espatas 2,5-7 cm compr., ápice arredondado a agudo, margem irregular, glabras. Escapos 10-26 cm compr., pubescentes. Brácteas involucrais douradas, $5-10 \times 2-3,5 \mathrm{~mm}$, triangulares, ápice agudo, recurvadas na maturidade, ultrapassando a altura das flores por $2-5 \mathrm{~mm}$, totalmente glabras. Capítulos alvos, 4-13 mm diâm. Flores de 108 a 146 por capítulo, 3 vezes mais estaminadas que pistiladas. Brácteas florais hialinas, 2-3×0,3-0,8 mm, lanceoladas, ápice agudo a acuminado, tufo de tricomas no ápice, ciliada. Flores estaminadas ca. $3 \mathrm{~mm}$ compr.; pedicelo ca. 0,3 mm compr.; sépalas hialinas, $0,5-1 \times$ $0,3 \mathrm{~mm}$, elípticas a oblanceoladas, ápice acuminado, tricomas em tufos na porção apical; corola hialina, 1,2-3 × 0,5-1 mm; estames 1-2 mm compr.; anteras creme. Flores pistiladas $2-3 \mathrm{~mm}$ compr., pedicelo ca. 0,2 mm compr.; sépalas hialinas, ca. $2 \times 0,4 \mathrm{~mm}$, oblanceoladas, ápice acuminado, tufo de tricomas na porção apical; pétalas hialinas, 1,5-2 ×0,5 mm, oblanceoladas, ápice acuminado, glabrescentes.

Material selecionado: Diamantina, Comunidade de Galheiros, 16.IX.2006, fl., F.N. Costa et al. 1098 (DIAM); estrada para Candeia Torta, 5.XI.2009, fl., C.O. Andrino et al. 22 (DIAM). Serro, trilha de Santo Antonio do Itambé para Pico do Itambé, 5.IV.1982, fl., N. Hensold 603 (SPF).

Paepalanthus chrysolepis possui hábito semelhante ao de $P$. calvulus e P. latifolius, porém, é distinguida por ser menor e mais delicada e pelas folhas com margem ciliada.

É endêmica do Planalto de Diamantina, ocorrendo principalmente na Serra do Pasmar e arredores, entre 1250 a 1500 metros de altitude (Fig. 1). Habita solos úmidos de fendas de rocha e base de afloramentos rochosos, em locais parcialmente sombreados. Estima-se que a área de ocorrência da espécie não ultrapasse $200 \mathrm{~km}^{2}$, e não está presente em qualquer UC, no entanto, não há dados suficientes para classificá-la quanto ao grau de ameaça.

Floresce praticamente em todos os meses do ano.

4. Paepalanthus comans Silveira, Floral. Mont. 262. 1928.

Fig. 2e-f

Erva $14-55 \mathrm{~cm}$ alt. Caule restrito à roseta. Folhas rosuladas, 3-13 × 0,2-1,1 cm, lanceoladas, agudas a obtusas, glabras em ambas as faces.
Espatas 3-11,5 cm compr., acuminadas, margem inteira, glabrescentes. Escapos 12-44 cm compr., pubescentes. Brácteas involucrais castanhoescuras, as externas um pouco mais claras que as internas, 4-7 × 2,5-5 mm, ovadas a triangulares, ápice agudo, raramente recurvadas na maturidade, ultrapassando a altura das flores por $0,8-3 \mathrm{~mm}$, glabras a pubescentes na face abaxial e pubescentes a lanosas no ápice da face adaxial. Capítulos alvos, 6-19 mm diâm. Flores de 125 a 146 por capítulo, 3 vezes mais estaminadas que pistiladas. Brácteas florais com pigmentação enegrecida na porção apical, 5-7 ×0,4 mm, lanceoladas, ápice arredondado a acuminado, tufo de tricomas na porção apical, ciliada. Flores estaminadas 5-6 mm compr.; pedicelo 0,5-1 mm compr.; sépalas hialinas, ápice levemente mais escuro que a base, 4-6 $60,5-1 \mathrm{~mm}$, elípticas a oblanceoladas, ápice acuminado, tricomas em tufos na porção apical; corola hialina, $2-5 \times$ 1,5-2 mm; estames 2-4 mm compr., anteras creme a castanho claras. Flores pistiladas $3-5 \mathrm{~mm}$ compr., pedicelo $0,8-1,2 \mathrm{~mm}$ compr.; sépalas hialinas, $3-5 \times 0,5-0,7 \mathrm{~mm}$, lineares a lanceoladas, ápice agudo a acuminado, tufo de tricomas na porção apical; pétalas hialinas, 3-4 ×0,6-1 mm, lineares a lanceoladas, ápice agudo, tricomas na porção apical. Material selecionado: Datas, 5-6 km S de Datas, na estrada para a Costa Sena, 23.II.1982, fl., N. Hensold 516 (MBM, SPF). Diamantina, estrada para ponte do "acaba-mundo", 28.XI.2003, fl., F.N. Costa et al. 712 (DIAM, SPF); estrada para Milho Verde, 25.IX.2009, fl., C.O. Andrino et al. 15 (DIAM). Gouveia, ligação rodovia BR- 259 a Costa Sena, 27.XI.1985, fl., G. Hatschbach et al. 50521 (SPF). Serro, a 2,5 km de Milho Verde, 22.II.1982, fl., N. Hensold 510 (MBM, SPF).

Paepalanthus comans pode ser facilmente reconhecida pela pigmentação enegrecida no ápice das brácteas florais, característica que pode ser vista em campo. Além disso, possuem as brácteas involucrais externas um pouco mais claras que as internas e as folhas bastante enrugadas quando secas, devido a características do mesofilo (Hensold 1988).

É endêmica dos campos rupestres do Planalto de Diamantina, sendo uma das espécies mais comuns (Fig. 1), juntamente com $P$. argenteus var. argenteus. Apesar de ser uma das espécies comercializadas na região, pode se afirmar que não está ameaçada, pois apresenta ampla distribuição na área de ocorrência e populações com numerosos indivíduos, ocorrendo inclusive dentro dos PE do Biribiri e do Rio Preto.

Floresce durante a estação chuvosa, entre os meses de outubro a abril. 
5. Paepalanthus dianthoides Mart. ex Koern., F1. bras. 3(1): 339. 1863.

Fig. 3a

Erva $30-45 \mathrm{~cm}$ alt. Caule alongado, $21-35 \mathrm{~cm}$ compr., 5-7 mm diâm. Folhas espiraladas, distribuídas ao longo do caule, $3-6 \times 0,2-0,5 \mathrm{~cm}$, lanceoladas, agudas, cuspidadas, glabras a pubescentes em ambas as faces. Espatas 4-5 cm compr., acuminadas a agudas, margem inteira, pubescentes. Escapos 10-26 cm compr., pubescentes. Brácteas involucrais castanho-escuras, 4-7 × 3-5 mm, triangulares, ápice agudo, ultrapassando as flores do capítulo por 1-2 mm, pubescentes. Capítulos alvos, 6-15 mm de diâm. Brácteas florais com pigmentação marrom no ápice, 5-6 × 0,5 mm, lineares a lanceoladas, agudas a subagudas, ciliada. Flores estaminadas 5-6 mm compr.; pedicelo 0,81,5 mm compr.; sépalas hialinas, 4-6 $\times 0,8-1 \mathrm{~mm}$, elípticas a oblanceoladas, ápice agudo a acuminado, tricomas filamentosos no ápice; corola hialina, 3-3,5 mm compr.; estames 3,5-4 mm compr., anteras marrons. Flores pistiladas $4-6 \mathrm{~mm}$ compr., pedicelo 0,3-0,4 mm compr.; sépalas hialinas, 5-6 $\times 0,4-0,5 \mathrm{~mm}$, lanceoladas, ápice agudo, glabras, tricomas no ápice; pétalas hialinas, $6 \times 0,5-0,6 \mathrm{~mm}$, lanceoladas, ápice agudo a acuminado, pubescentes na face adaxial, glabras na face abaxial.

Material examinado: Serro, estrada para Milho Verde, 8.IV.2010, fl., C.O. Andrino 35 (DIAM).

Material adicional examinado: MINAS GERAIS, Barão de Cocais, Serra do Garimpo, $10 \mathrm{~km}$ ao noroeste de Barão de Cocais, 12.I.1982, fl., N. Hensold CFCR 3670 (SPF). Santa Bárbara, Serra do Caraça, ao norte do Pico da Conceição (Monte da Boa Vista), 6.III.1982, fl., N. Hensold 530 (SPF).

Paepalanthus dianthoides pode ser distinguida pelo caule visivelmente alongado e escandente, pelas folhas cuspidadas no ápice e pelas brácteas involucrais ultrapassando a altura das flores no capítulo em apenas 1-2 $\mathrm{mm}$.

Ocorre na Serra do Caraça e Serra do Garimpo, no sul do Espinhaço (Hensold 1988) e também na porção sul da Serra do Cipó, onde é conhecida por apenas uma coleta (Hensold 1998). Recentemente, foi registrada uma população disjunta no Planalto de Diamantina (Echternacht et al. 2011a) e, no presente trabalho, foi descoberta mais uma população. Hensold (1988) cita um registro duvidoso para a Serra do Cabral, não tendo sido confirmada sua ocorrência, e provavelmente trata-se mesmo de etiquetas trocadas, como inferido pela autora. Habita solos pedregosos, geralmente associados a gramíneas e arbustos, diferente do que é reportado por Hensold (1998) para as outras áreas de ocorrência, onde os indivíduos ocorrem próximos à vegetação densa e arbustiva ou em mata ciliar.

Apesar do baixo número de populações na área de estudo, provavelmente a espécie não está ameaçada de extinção, sendo o Planalto de Diamantina o extremo norte da distribuição da espécie.

Paepalanthus dianthoides possui registros de coleta nos meses de novembro a maio, mas não é possível afirmar que este seja o período típico de floração devido ao pequeno volume de material coletado.

\section{Paepalanthus homomallus (Bong.) Mart. ex} Koern., F1. bras. 3(1): 340. $1863 . \quad$ Fig. 3c-d Erva $10-20 \mathrm{~cm}$ alt. Caule restrito à roseta. Folhas rosuladas, 3-6 × 0,1-0,3 mm, lineares, ápice arredondado, pubescentes a lanuginosas em ambas as faces. Espatas 2-3 cm compr., acuminadas a agudas, inteiras, pubescentes. Escapos 7-15 cm compr., pubescentes. Brácteas involucrais castanho-escuras a castanhas, 2-4 $\times$ 2-3 mm, lanceoladas, agudas, não ultrapassando a altura das flores, pubescentes. Capítulos ocre, 6-11 mm diâm. Flores de 160 a 255 por capítulo, 9 vezes mais estaminadas que pistiladas. Brácteas florais hialinas, 2-3 × $0,1-0,3 \mathrm{~mm}$, lineares, aguda a subaguda, tufo de tricomas no ápice, ciliada. Flores estaminadas 3-4 mm compr.; pedicelo ca. $1 \mathrm{~mm}$ compr.; sépalas hialinas, $2-2,5 \times 0,3-0,5 \mathrm{~mm}$, elípticas a oblanceoladas, ápice agudo a acuminado, tufos de tricomas na porção apical; corola hialina, 1-1,5 mm compr.; estames 2-3 mm compr., anteras creme. Flores pistiladas 3-3,5 $\mathrm{mm}$ compr., pedicelo 0,4-0,6 mm compr.; sépalas hialinas, 2,5-3 × 0,3-0,4 $\mathrm{mm}$, lanceoladas, ápice agudo, tufos de tricomas na porção apical; pétalas hialinas, 1,5-2 × 0,5$0,7 \mathrm{~mm}$, lanceoladas, ápice agudo a acuminado, tufos de tricomas na porção apical.

Material examinado: Conceição do Mato Dentro, a $9 \mathrm{~km}$ de Congonhas do Norte, estrada para Gouveia, 20.IV.1982, fl., N. Hensold 711 (SPF). Congonhas do Norte, Leste da Serra do Cipó, a sudoeste de Congonhas do Norte, 21.IV.1982, fl., N. Hensold 732 (SPF); estrada Congonhas do Norte para Gouveia, ca. 2 km após Congonhas do Norte, 10.VII.2008, fl., L. Echternacht 1750 (BHCB, SPF). Datas, estrada para Congonhas do Norte, ca. $500 \mathrm{~m}$ após a entrada, acesso pela rodovia Datas-Serro, 27.I.2004, fl., F.N. Costa \& P.N. Costa 731 (DIAM); caminho para Costa Sena, 18.III.2011, fl., C.O. Andrino et al. 117 (DIAM).

Paepalanthus homomallus possui flores muito pequenas, podendo ser facilmente reconhecida 


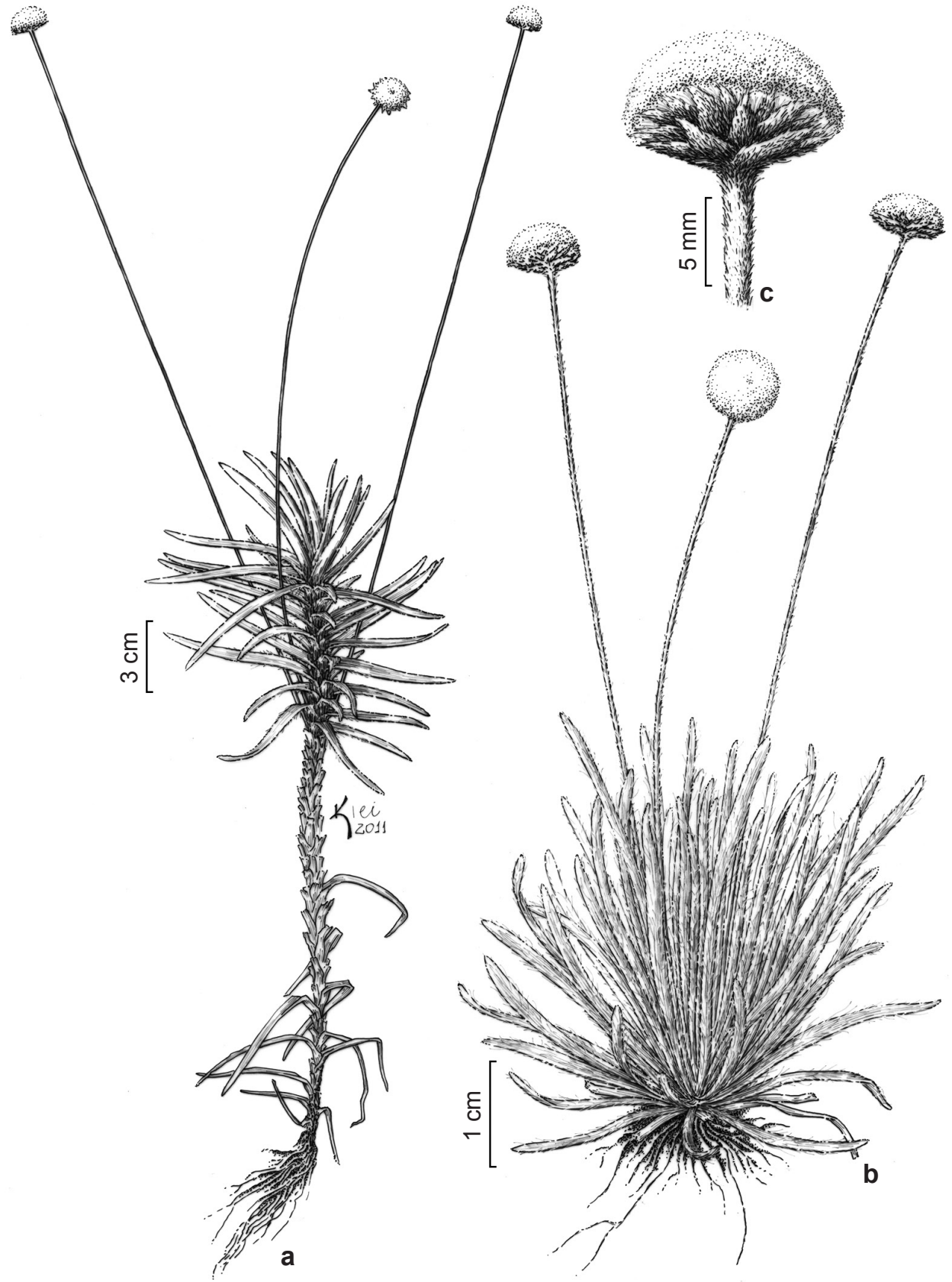

Figura 3 - a-b. Paepalanthus dianthoides - a. hábito (C.O.Andrino 35 (DIAM)). b-c. P. homomallus - b. hábito; c. capítulo (F.N.Costa 731(DIAM)).

Figure 3 - a-b. Paepalanthus dianthoides - a. habit (C.O.Andrino 35 (DIAM)). b-c. P. homomallus - b. habit; c. capitulum (F.N.Costa 731(DIAM)).

pelas folhas lineares pilosas com ápice arredondado e pelas brácteas involucrais que não ultrapassam a altura das flores (Fig. 3d).

Ocorre no norte da Serra do Cipó e extremo sul do Planalto de Diamantina (Fig. 1), habitando áreas campestres, em solos arenosos e úmidos. Devido à distribuição restrita e às populações com poucos indivíduos, pode se inferir que esta espécie encontrase sobre algum grau de ameaça, embora seja difícil classificá-la segundo os critérios da IUCN (2001).

Foram coletados indivíduos com flores entre janeiro e julho. 
7. Paepalanthus latifolius (Bong.) Koern., Fl. bras. 3(1): 344. 1863.

Erva $30-50 \mathrm{~cm}$ alt. Caule restrito à roseta. Folhas rosuladas, 9-22 × 0,9-2,7 cm, lanceoladas, agudas a subagudas, glabrescentes em ambas as faces. Espatas 2,5-7 cm compr., agudas, margens irregulares, glabrescentes. Escapos 10-31 cm compr., glabrescentes. Brácteas involucrais creme a douradas, $6-10 \times 2-4 \mathrm{~mm}$, triangulares a lanceoladas, agudas, ultrapassando as flores do capítulo em 3-7 mm, glabrescentes. Capítulos alvos, 7-16 mm diâm. Brácteas florais hialinas, 7-8 $\times 0,5 \mathrm{~mm}$, lanceoladas, agudas, tufo de tricomas na porção apical, ciliada. Flores estaminadas 5-7 mm compr.; pedicelo 0,4-0,6 mm compr.; sépalas hialinas, 5-6 ×0,8-1 mm, elípticas a oblanceoladas, ápice agudo a acuminado, tricomas em tufos na porção apical; corola hialina, 3,5-5 $\mathrm{mm}$ compr.; estames 4,5-6 $\mathrm{mm}$ compr., anteras creme. Flores pistiladas 6-7 mm compr., pedicelo 0,2-0,6 mm compr.; sépalas hialinas, $6-7 \times 1 \mathrm{~mm}$, lanceoladas, ápice agudo a acuminado, glabras; pétalas hialinas, $4 \times 1,5 \mathrm{~mm}$, lanceoladas, ápice acuminado, pubescentes na face adaxial e glabras na face abaxial.

Material selecionado: Diamantina, ca. $53 \mathrm{~km}$ de Diamantina, entre Diamantina e Curvelo, BR 259/367, 4.XII.1981, fl., N. Hensold 361 (MBM, SPF). Gouveia, nos arredores da torre de rádio, a oeste da Fazenda Contagem, 9.IV.1982, fl., N. Hensold 649 (SPF); 12 $\mathrm{km}$ da BR 259, entre Gouveia e Curvelo, 9.IV.1982, fl., N. Hensold 659 (SPF). Córrego do Tigre, 14.IX.1985, fl., G. Hatschbach 49648 (MBM, SPF); a $22 \mathrm{~km}$ da cidade de Gouveia, em estrada de terra para torre de telefonia, a $2 \mathrm{~km}$ da rodovia (BR 259), 20.VIII.1990, fl., R. Mello-Silva et al. 364 (RB, SPF); estrada de terra ao lado da usina é́lica, 13.V.2010, fr., C.O. Andrino et al. 55 (DIAM). Presidente Juscelino, ca. $16 \mathrm{~km}$ da cidade em direção a Diamantina, 9.II.1994, fl., R.M. Harley et al. CFCR 139992 (SPF).

Paepalanthus latifolius e $P$. argenteus são duas espécies filogeneticamente próximas (Echternacht et al. 2011a), e compartilham diversas características morfológicas, mas podem ser diferenciadas principalmente pela pilosidade das folhas e pelo tamanho das flores.

É endêmica do sul do Planalto de Diamantina (Fig. 1), ocorrendo em altitudes entre 1100-1250 m, em áreas úmidas, em solos orgânicos ou em fendas de rocha, em sombra parcial, geralmente associada a gramíneas, arbustos e arvoretas. Embora o tipo tenha sido coletado na Serra do Cipó, não foram encontrados materiais provenientes desta localidade. A área de ocorrência desta espécie é bastante restrita e as populações não contam com muitos indivíduos, além de ocorrer em áreas próximas à beira de estradas e rodovias e fora de UCs. Com base nestas informações, pode se inferir que a espécie encontra-se ameaçada, embora seja difícil classificá-la segundo os critérios da IUCN (2001).

Foi coletada com flores em dezembro e abril, e em maio com capítulos passados.

8. Paepalanthus mollis var. itambeensis Hensold, Syst. Bot. Monogr. 23: 103. $1988 . \quad$ Fig. 4a-b

Erva $15-23 \mathrm{~cm}$ alt. Caule alongado, $2-10 \mathrm{~cm}$ compr. Folhas rosuladas ou dispostas ao longo do caule, $3,5-5 \times 0,2-0,3 \mathrm{~cm}$, lineares, arredondadas a acuminadas, glabras a pubescentes em ambas as faces. Espatas 5-6 cm de compr., agudas, margens inteiras, glabrescentes. Escapos 13-15 cm compr., glabrescentes. Brácteas involucrais castanhoescuras $4-7 \times 2-4 \mathrm{~mm}$, triangulares a ovadas, ápice agudo a obtuso, ultrapassando a altura das flores por 4-6 mm, glabrescentes na face abaxial, densamente lanosas na porção apical da face adaxial. Capítulos alvos, 6-12 mm diâm. Flores de 52 a 86 por capítulo, 6 vezes mais estaminadas que pistiladas. Brácteas florais com pigmentação enegrecida no ápice, ca. $4 \times 0,3 \mathrm{~mm}$, lineares a lanceoladas, agudas, ciliadas com tufo de tricomas na porção apical. Flores estaminadas $3,5-4,5 \mathrm{~mm}$ compr.; pedicelo 0,4-0,6 mm compr.; sépalas com pigmentação enegrecida na porção apical, ca. $4 \times 0,5 \mathrm{~mm}$, obovadas, ápice arredonado, tricomas em tufo na porção apical; corola com pigmentação enegrecida a partir do terço superior, ca. 4,5 mm compr.; estames ca. $4 \mathrm{~mm}$ compr., anteras castanhas. Flores pistiladas ca. 0,4 mm compr.; pedicelo ca. 0,2 mm compr.; sépalas com pigmentação enegrecida em toda a sua extensão, ca. 4,5 $\times 0,7 \mathrm{~mm}$, lanceoladas, ápice obtuso a acuminado, com tufo de tricomas na porção apical; pétalas com pigmentação enegrecida em toda a sua extensão, ca. $3 \times 1,5 \mathrm{~mm}$, lanceoladas, ápice arredondado, pubescente adaxialmente, glabras abaxialmente, margem ciliada.

Material selecionado: Santo Antonio do Itambé, a 18 $\mathrm{km}$ da cidade, no alto do Pico do Itambé, 16.VII.1987, fl., D.C. Zappi et al. CFCR 11259 (SPF); Parque Estadual do Pico do Itambé, Alto do Pico do Itambé, $2050 \mathrm{~m}$, 22.IV.2010, fl., F.N. Costa et al. 1281 (DIAM, SPF).

Paepalanthus mollis var. itambeensis pode ser distinguida pelos indivíduos cespitosos, pela estatura pequena, pelo escapo curto, e pelas flores diminutas. 


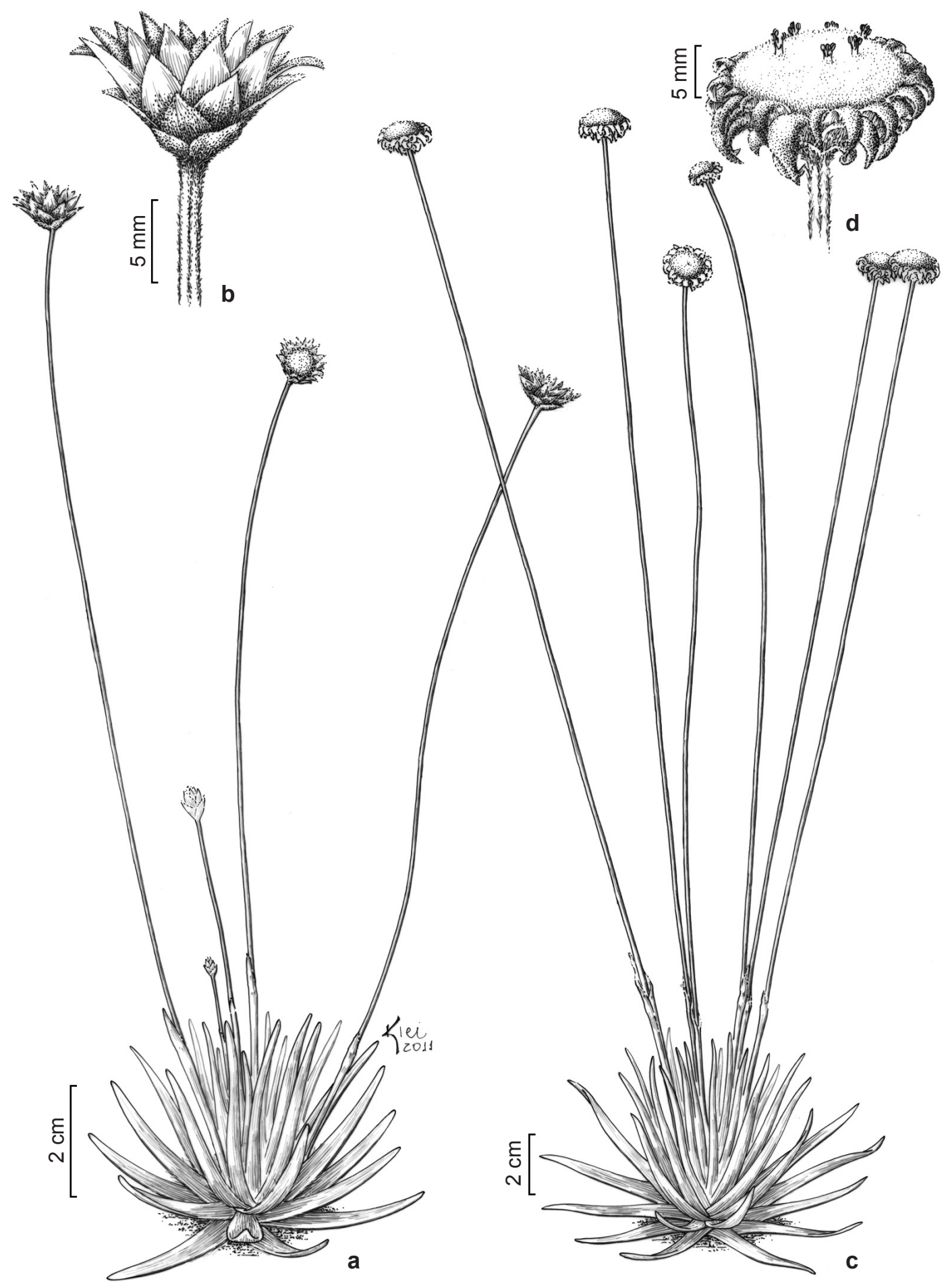

Figura 4 - a-b. Paepalanthus mollis var. itambeensis - a. hábito; b. capítulo (A.S.Quaresma 98 (DIAM)). c-d. P. plumosus - c. hábito; d. capítulo (C.O.Andrino 58 (DIAM)).

Figure 4 - a-b. Paepalanthus mollis var. itambeensis - a. habit; b. capitulum (A.S.Quaresma 98 (DIAM)). c-d. P. plumosus - c. habit; d. capitulum (C.O.Andrino 58 (DIAM)). 
A variedade tipo desta espécie é restrita ao Pico do Itacolomi e Serra do Caraça e pode ser diferenciada de $P$. mollis var. itambeensis principalmente por suas dimensões, textura das folhas e pelas brácteas involucrais. A variedade registrada aqui é endêmica do PE do Pico do Itambé, ocorrendo apenas no alto do Pico, acima de $2040 \mathrm{~m}$ de alt. (Fig. 1 ), em populações com muitos indivíduos, entre fendas de rochas, em solo arenoso quartzítico raso e expostas ao sol.

Embora a espécie não conste na lista de espécies ameaçadas, e seja difícil classificá-la segundo os critérios da IUCN (2001), pode se afirmar que a mesma está sobre elevado grau de ameaça, devido a distribuição restrita a somente uma localidade.

Floresce entre os meses de dezembro e junho.

\section{Paepalanthus nigrescens Silveira, Fl. Serr. Min.} 62. 1908.

Erva $15-40 \mathrm{~cm}$ alt. Caule restrito à roseta. Folhas rosuladas, $3-11 \times 0,3-1,5 \mathrm{~cm}$, lanceoladas, agudas a obtusas, glabrescentes em ambas as faces. Espatas 5-13 cm compr., agudas, margens inteiras, glabrescentes. Escapos 11-40 cm compr., glabrescentes a densamente seríceos. Brácteas involucrais castanho-escuras, 3,1-5 × 2,7-5 mm, ovadas, acuminadas ou obtusas, não ultrapassando a altura das flores, pubescentes a lanosas. Capítulos alvos a ocre, 6-16 mm de diâm. Flores de 340 a 420 por capítulo, 6 vezes mais estaminadas que pistiladas. Brácteas florais com pigmentação enegrecida na porção apical, ca. $4 \times 0,5 \mathrm{~mm}$, lanceoladas, agudas, tufo de tricomas na porção apical. Flores estaminadas 4-6 mm compr.; pedicelo 0,7-1 mm compr.; sépalas com pigmentação castanha a enegrecida na metade superior, 3-4 × 1-1,2 mm, oblanceoladas, tricomas em tufo na porção apical; corola hialina, ca. $3,5 \mathrm{~mm}$ compr.; estames ca. $3 \mathrm{~mm}$ compr., anteras creme. Flores pistiladas ca. $4 \mathrm{~mm}$ compr., sésseis; sépalas com pigmentação enegrecida na metade superior, 2,5-5× 0,9-1,1 mm, oblongas a obovadas, tricomas em tufos na porção apical; pétalas com pigmentação enegrecida na metade superior, 3-4 ×0,9-1 mm, oblongas a obovadas, tricomas em tufos na porção apical.

Material examinado: Presidente Kubitschek, Estrada Datas-Serro, 20.II.1982, fl., N. Hensold 527 (MBM, $\mathrm{SPF}) ; 9 \mathrm{~km}$ após a entrada para Costa Sena, na rodovia à esquerda, 25.XI.2010, fl., C.O. Andrino et al. 97 (DIAM). Material adicional examinado: MINAS GERAIS: Itambé do Mato Dentro, Serra do Cipó, 11.V.1982, fl., N. Hensold 819 (SPF). Jaboticatubas, Serra do Cipó, margem da estrada Belo Horizonte - Conceição do Mato Dentro, km 126, 6.IX.1976, fl., W. Monteiro 16 (SPF).
Santa Luzia, Serra do Cipó, 23.VIII.1993, fl., Mello Barreto 2537 (SPF). Santana do Riacho, Serra do Cipó, 23.X.1997, fl., P.T. Sano et al. 648 (SPF).

Paepalanthus nigrescens é distinguida pelas brácteas involucrais marrons, todas do mesmo tamanho, não ultrapassando a altura das flores, além de anteras creme. Devido às brácteas involucrais mais curtas que as flores, P. nigrescens é facilmente confundida com espécies pertencentes à $P$. subgen. Paepalocephalus Ruhland, no entanto, estas nunca apresentam o interior do tubo da corola piloso.

É uma das espécies mais comuns do subgênero estudado e abundante na porção sul da Serra do Cipó (Hensold 1998), ocorrendo em solo perturbado de beira de estradas, a 1000-1500 m alt. $\mathrm{Na}$ área de estudo é conhecida apenas de uma única população, no sul do Planalto de Diamantina, por uma coleta feita na década de 1980 e outra recente (Fig. 1). Apesar de pouco representada na área de estudo, a espécie não se encontra sobre qualquer grau de ameaça ao longo de sua distribuição.

Para a Serra do Cipó, há registros de floração durante o ano todo, mas o mesmo não se pode afirmar para a área de estudo devido ao pequeno número de material examinado.

10. Paepalanthus plumosus (Bong.) Koern., Fl. bras. 3(1): 337. 1863. Fig. $4 c-d$

Erva ca. $20-40 \mathrm{~cm}$ alt. Caule restrito à roseta. Folhas rosuladas, $4-9,5 \times 0,2-0,5 \mathrm{~cm}$, lineares a lanceoladas, agudas, glabras a pubescentes em ambas as faces. Espatas 8-9 cm compr., acuminadas a agudas, inteiras, glabrescentes. Escapos 29-38 $\mathrm{cm}$ compr., glabrescentes. Brácteas involucrais castanho-escuras, 6-11 × 2-5 mm, triangulares, agudas a subagudas, ultrapassando a altura das flores em 4-8 mm, pubescentes na face abaxial, densamente lanosas no ápice da face adaxial. Capítulos alvos, 13-18 mm de diâm. Flores de 37 a 62 por capítulo, 4 vezes mais estaminadas que pistiladas. Brácteas florais com pigmentação enegrecida nas margens, ca. $6 \times 1 \mathrm{~mm}$, lanceolada, ápice agudo a acuminado, ciliada. Flores estaminadas 5-6 mm compr.; pedicelo ca. $2 \mathrm{~mm}$ compr.; sépalas hialinas, $3-4 \times 0,5 \mathrm{~mm}$, elípticas a oblanceoladas, ápice arredondado, tricomas em tufos na porção apical; corola hialina, 3-4 mm compr.; estames ca. $3,5 \mathrm{~mm}$ compr., anteras marrons. Flores pistiladas 4-6 mm compr., pedicelo ca. $1 \mathrm{~mm}$ compr.; sépalas hialinas, 5-6 × 0,4-0,6 mm, lineares, ápice agudo, longos tricomas no ápice e nas margens; pétalas hialinas, 4,5-6 $62 \mathrm{~mm}$, lineares, ápice agudo, com tricomas na porção apical. 
Material examinado: Congonhas do Norte, Serra do Cipó, 23.IV.1982, fl., N. Hensold 750 (MBM, SPF). Serra Talhada, 2.III.1998, fl., J.R. Pirani et al. 4143 (SPF); Serra da Carapina, estrada Congonhas do Norte para Gouveia, ramificação à esquerda rumo à Serra Talhada, 10.IV.2009, fl., L. Echternacht et al. 1977 (BHCB, SPF); $11 \mathrm{~km}$ distante de Extrema, subindo a Serra, limite do Parque Estadual Serra do Intendente, 17.VI.2010, fl., C.O. Andrino et al. 70 (DIAM).

Paepalanthus plumosus é facilmente confundida com $P$. comans, mas pode ser diferenciada pela consistência mais firme das folhas, pelas brácteas involucrais mais longas e pela ausência de pigmentação enegrecida do ápice da bráctea floral, presente em $P$. comans.

É endêmica da porção norte da Serra do Cipó, no município de Congonhas do Norte (Fig. 1), formando grandes populações em áreas de campos rupestres.

Foi coletada com flores de março a junho.

11. Paepalanthus revolutus Hensold, Syst. Bot. Monogr. 23: 94. 1988.

Fig. 5a-b

Erva ca. $30 \mathrm{~cm}$ alt. Caule alongado, até 20 cm compr. Folhas espiraladas distribuídas ao longo do caule, 5-7,5 × 0,2-0,3 cm, lineares, agudas ou subagudas, glabrescentes em ambas as faces. Espatas 5-6,5 cm compr., acuminadas a agudas, margens inteiras, glabrescentes. Escapos 13-26 cm de compr., pubescentes. Brácteas involucrais castanho-escuras, 6-11 × 4-6 mm, triangulares a lanceoladas, agudas, fortemente recurvadas, ultrapassando a altura das flores em 4-6 mm, face adaxial lanosa, face abaxial glabrescente. Capítulos alvos, 4-11 mm diâm. Flores de 47 a 96 por capítulo, 7 vezes mais estaminadas que pistiladas. Brácteas florais com pigmentação enegrecida a partir do terço superior, 5-6 $\times$ 0,7-1 mm, lineares a lanceoladas, ápice agudo a acuminado, com tufos de tricomas, ciliada. Flores estaminadas 5-6 mm compr., pedicelo 1,5 $\mathrm{mm}$ compr.; sépalas com pigmentação enegrecida homogênea, $5 \times 0,5 \mathrm{~mm}$, elípticas a oblanceoladas, tricomas em tufo na porção apical; corola com pigmentação enegrecida, 3,5-4 mm compr.; estames 4-6 mm compr., anteras castanho-escuras. Flores pistiladas 5-6 mm compr., pedicelo ca. 0,4 mm compr.; sépalas com pigmentação enegrecida 5-6 $\times$ 0,4-0,6 mm, lanceoladas, com tufo de tricomas na porção apical, pétalas com pigmentação enegrecida, 5-6 × 1,5-2 mm, lanceoladas, ápice agudo, com tufos de tricomas na porção apical.

Material examinado: Congonhas do Norte, $2 \mathrm{~km}$ ao Sul de Conceição do Mato Dentro, 20.IV.1982, fl., $N$. Hensold 705 (SPF); 2 km ao Sul de Conceição do Mato Dentro, 20.IV.1982, fl., N. Hensold 518 (SPF); estrada de Conceição do Mato Dentro para Congonhas do Norte, 17.VI.2010, fl., C.O. Andrino et al. 71 (DIAM).

Paepalanthus revolutus tem esse nome em referência à tendência das brácteas involucrais se recurvarem fortemente, mesmo no botão.

É endêmica da porção norte da Serra do Cipó, sendo conhecida de uma única população, na margem de uma estrada que está sendo pavimentada (Fig. 1). Embora a espécie não conste na lista de espécies ameaçadas, e seja difícil classificá-la segundo os critérios da IUCN (2001), pode se afirmar que a mesma está sobre elevado grau de ameaça.

Foi coletada com flor nos meses de fevereiro, abril e junho.

12. Paepalanthus superbus Ruhland, Pflanzenr. IV, 30: 218. 1903

Fig. 5c-d

Erva $25-40 \mathrm{~cm}$ alt. Caule alongado, $10-30 \mathrm{~cm}$ compr. Folhas alternas dísticas, $2-8 \times 0,2-0,6 \mathrm{~cm}$, lanceoladas, agudas a obtusas, glabrescentes. Espata 3-5 cm compr., acuminadas a agudas, margens inteiras, glabras a pubescentes. Escapos $10-30 \mathrm{~cm}$ compr., glabrescentes. Brácteas involucrais castanhoescuras, 2-13 × 2-6 mm, ovadas a triangulares, agudas, ultrapassando a altura das flores por 1-6 $\mathrm{mm}$, pubescentes em ambas as faces. Capítulos alvos, 3-16 mm diâm. Flores de 176 a 245 por capítulo, 10 vezes mais estaminadas que pistiladas. Brácteas florais castanho-escuras a castanhas, 6-7 × 0,7-1 $\mathrm{mm}$, lineares a lanceoladas, agudas a acuminadas, com tufos de tricomas na porção apical, ciliadas. Flores estaminadas 5-6 mm compr., pedicelo ca. 2 mm compr.; sépalas castanho-escuras, 5-6 × 0,8-1 $\mathrm{mm}$, elípticas a oblanceoladas, tricomas em tufo na porção apical; corola com pigmentação negra, 3,5-4 mm compr.; estames 3-5 mm compr., anteras creme a castanhas. Flores pistiladas 3-6 mm compr., pedicelo ca. 0,1 mm compr.; sépalas castanho-escuras na porção apical, 4-5 × 0,8-1 mm, lanceoladas, ápice agudo, com tufos de tricomas no ápice; pétalas castanho-escuras, 5-6×1,5-2 mm, lanceoladas, ápice agudo a acuminado, glabras.

Material examinado: Congonhas do Norte, Fechados, sudoeste de Congonhas do Norte, 23.IV.1982, fl., N. Hensold 753 (SPF); estrada no alto da Serra a aproximadamente 15 km de Congonhas do Norte, 16.VI.2010, fl., C.O. Andrino et al. 58 (DIAM); $11 \mathrm{~km}$ distante de Extrema, limite do Parque Estadual Serra do Intendente, 17.VI.2010, fl., C.O. Andrino et al. 70 (DIAM).

Paepalanthus superbus distingue-se das demais espécies pelas pétalas escuras, que são muitas vezes fundidas na base e corolas pretas com pigmentação enegrecida granular, esta última apontada como 


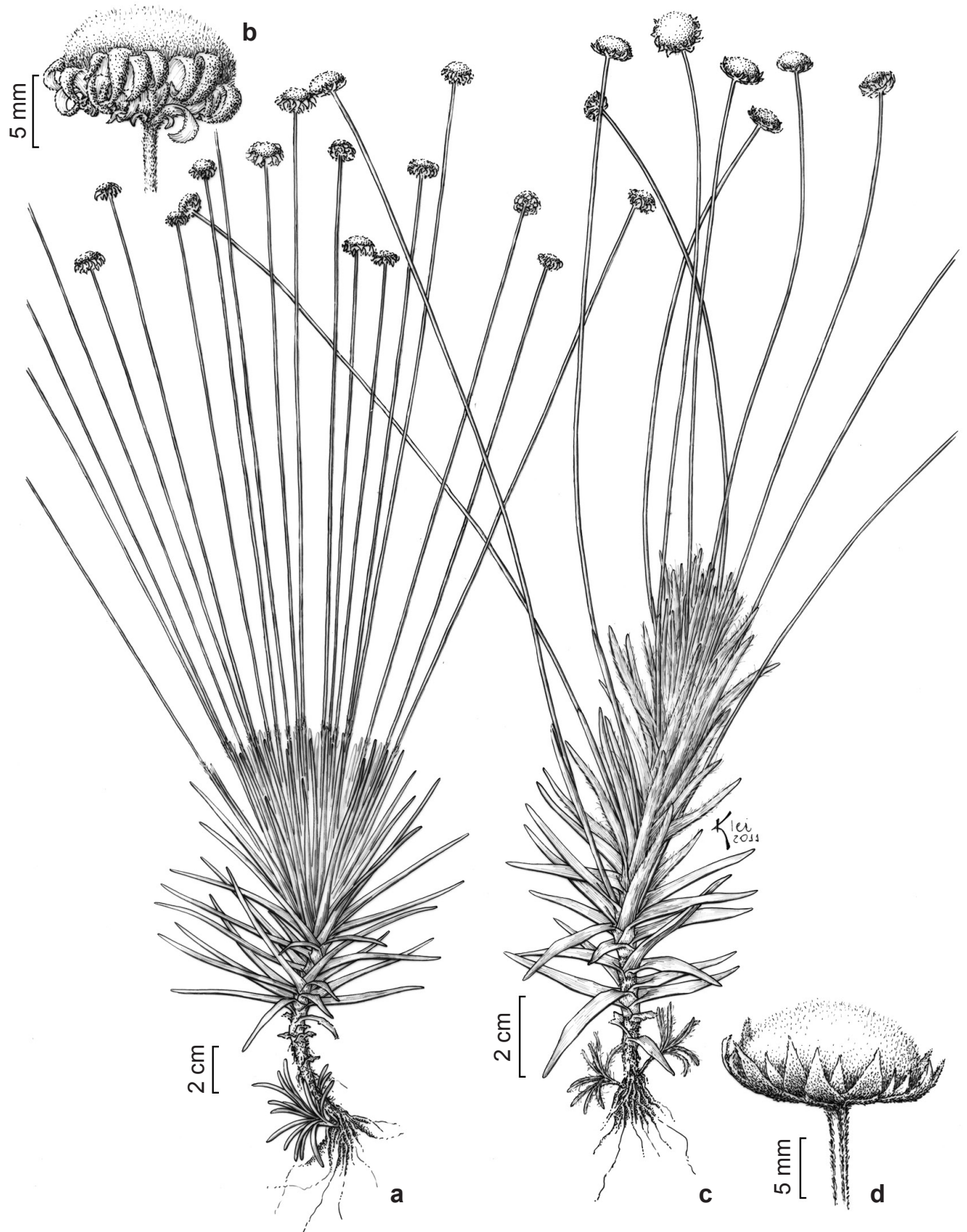

Figura 5 - a-b. Paepalanthus revolutus - a. hábito; b. capítulo (C.O.Andrino 71 (DIAM)). c-d. P. superbus - c. hábito; d. capítulo (C.O.Andrino 60 (DIAM)).

Figure 5 - a-b. Paepalanthus revolutus - a. habit; d. capitulum (C.O.Andrino 71 (DIAM)). c-d. P. superbus - c. habit; d. capitulum (C.O.Andrino 60 (DIAM)).

sinapomorfia de $P$. superbus e P. revolutus (Echternacht et al. 2011a). Esta espécie possui três variedades, sendo que na área de estudo há registros de ocorrência de $P$. superbus var. gracilis e $P$. superbus var. niveo-niger. No entanto, há poucas coletas desta espécie e um dos materiais examinados (C.O. Andrino et al. 70), não apresenta características que permitam identificá-lo ao nível de variedade. Foi observada sobreposição em relação ao número de escapos, comprimento das brácteas involucrais e altura em que estas ultrapassam as flores, entre outras. Portanto, optou-se neste estudo, não tratar este táxon no nível de variedade. 
Ocorre apenas no norte da Serra do Cipó e nas serras de Congonhas do Norte, entre 1150$1300 \mathrm{~m}$ alt. (Fig. 1).

Foi coletada com flores apenas na estação seca, nos meses de abril e junho.

\section{Agradecimentos}

À Fundação de Amparo à Pesquisa do Estado de Minas Gerais - FAPEMIG, o auxílio financeiro ao projeto CRA-01077-08; ao Rafael, a elaboração do mapa; ao Klei, as ilustrações; aos curadores dos herbários citados; aos gerentes das UCs visitadas, a solicitude e atenção; e aos dois revisores anônimos suas valiosas sugestões.

\section{Referências}

Costa, F.N. 2005. Recircunscrição de Actinocephalus (Koern.) Sano - Eriocaulaceae. Tese de Doutorado. Universidade de São Paulo, São Paulo. 138p.

Costa, F.N. 2006. Three new species of Actinocephalus (Koern.) Sano (Eriocaulaceae) from Minas Gerais. Novon 16: 212-215.

Costa, F.N.; Trovó, M.; Sano, P.T. 2008. Eriocaulaceae na Cadeia do Espinhaço: riqueza, endemismos e ameaças. Megadiversidade 4: 89-97.

Drummond, G.M.; Martins, C.S.; Machado, A.B.M.; Sebaio, F.A. \& Antonini, Y. 2005. Biodiversidade em Minas Gerais: um atlas para sua conservação. Fundação Biodiversitas, Belo Horizonte. 222p.

Echternacht, L.; Trovó, M. \& Sano, P.T. 2010. Rediscoveries in Eriocaulaceae: seven narrowly distributed taxa from the Espinhaço Range in Minas Gerais, Brazil. Feddes Repertorium 121: 117-126.

Echternacht, L; Sano, P.T; Trovó, M. \& Dubuisson, J.Y. 2011a. Phylogenetic analysis of the Brazilian microendemic Paepalanthus subgenus Xeractis (Eriocaulaceae) inferred from morphology. Botanical Journal of the Linnean Society 167: 137-152.

Echternacht, L.; Trovó, M. \& Sano, P.T. 2011b. Two new species of Actinocephalus (Eriocaulaceae) from Minas Gerais, Brazil. Phytotaxa 27: 26-36

Forzza, R.C.; Baumgratz, J.F.A.; Costa, A.; Hopkins, M.; Leitman, P.M.; Lohmann, L.G.; Martinelli, G.; Morim, M.P.; Coelho, M.A.N.; Peixoto, A.L.; Pirani, J.R.; Queiroz, L.P.; Stehmann, J.R.; Walter, B.M.T.; Zappi, D. 2010. Angiospermas do Brasil. In: Forzza et al (eds.). Catálogo de plantas e fungos do Brasil. Vol. 1. Jardim Botânico do Rio de Janeiro, Rio de Janeiro. Pp. 79-89.

Giulietti, A.M. \& Hensold, N. 1990. Padrões de distribuição geográfica dos gêneros de Eriocaulaceae. Acta Botanica Brasilica 4: 133-158.
Giulietti, A.M.; Andrade, M.J.G; Scatena, V.L.; Trovó, M.; Coan, A.I.; Sano, P.T.; Santos, F.A.R; Borges, R.L.B.; van den Berg, C. 2012. Molecular phylogeny, morphology and their implications for the taxonomy of Eriocaulaceae. Rodriguésia 63: 1-19.

Hensold, N. 1988. Morphology and systematics of Paepalanthus subgenus Xeractis (Eriocaulaceae). Systematic Botany Monographs 23. The American Society of Plants Taxonomists, Michigan. 150p.

Hensold, N. 1996. Paepalanthus subgen. Xeractis (Eriocaulaceae): Notes and nomenclatural changes. Phytologia 81: 24-27.

Hensold, N. 1998. Flora da Serra do Cipó, Minas Gerais: Paepalanthus subgen. Xeractis (Eriocaulaceae). Boletim de Botânica da Universidade de São Paulo 17: 207-218.

IUCN (World Conservation Union). 2001. IUCN red list categories and criteria: version 3.1. IUCN Species Survival Commission, Gland and Cambridge. 33p.

Köppen, W. 1931. Climatologia. Fondo de Cultura Económica, Buenos Aires. 338p.

Ruhland, W. 1903. Eriocaulaceae. In: Engler, A. (ed.). Das Pflanzenreich. Vol. 4. Wilhelm Engelmann, Leipzig. Pp. 1-249.

Radford, A.E. 1974. Vascular plant systematics. Harper \& Row, New York. 891p.

Sano, P.T. 1999. Revisão de Actinocephalus (Koern.) Sano - Eriocaulaceae. Tese de Doutorado. Universidade de São Paulo, São Paulo. 241p.

Thiers, B. 2012. Index Herbariorum: a global directory of public herbaria and associated staff. New York Botanical Garden's Virtual Herbarium. Disponível em $<$ http://sweetgum.nybg.org/ih/>. Acesso em 15 Mar 2012.

Tissot-Squali, H.M.L. 1997. Monographische Bearbeintung von Paepalanthus subgenus Platycaulon. J. Cramer, Berlin. 242p.

Trovó, M. \& Costa, F.N. 2009. Actinocephalus koernickeanus, a new species of Eriocaulaceae from Minas Gerais, Brazil. Novon 19: 256-258.

Trovó, M. 2010. Sistemática de Paepalanthoideae: filogenia, morfologia e taxonomia de Diphyomene (Ruhland) Trovó. Tese de Doutorado. Universidade de São Paulo, São Paulo. 245p.

Trovó, M. \& Sano, P. T. 2010. Actinocephalus verae a new species from the Brazilian Campos Rupestres. Brittonia 62: 35-38.

Trovó, M.; Costa, F.N. \& Echternacht, L. 2012. Actinocephalus pachyphyllus: reestablishment, redefinition, and a new combination in Eriocaulaceae from Brazil. Kew Bulletin 67: 1-7. 